\title{
STUDI KOMPARATIF TENTANG PENINGKATAN KEMAMPUAN BERPIKIR KRITIS MATEMATIS SISWA MTs YANG MEMPEROLEH PEMBELAJARANDENGAN PENDEKATAN PROBLEM POSING DAN PEMBELAJARAN LANGSUNG
}

\author{
Rini Trisnawati' ${ }^{1}$, Wahyudin ${ }^{2)}$, Kusnandi ${ }^{3)}$ \\ ${ }^{1}$ SMP Negeri 12 Pekanbaru, Jalan Guru H. Sulaiman No.37 Pekanbaru, \\ trisnawatirini62@yahoo.com \\ ${ }^{2}$ Universitas Pendidikan Indonesia, Jalan Dr. Setiabudhi No.229 Bandung, \\ Wahyudin_mat@yahoo.com \\ ${ }^{3}$ Universitas Pendidikan Indonesia, Jalan Dr. Setiabudhi No.229 Bandung, \\ Kusnandiabadi@yahoo.co.id
}

\begin{abstract}
ABSTRAK
Penelitian ini bertujuan untuk menelaah peningkatan kemampuan berpikir kritis matematis siswa yang memperoleh pembelajaran dengan pendekatan problem posing dan siswa yang memperoleh pembelajaran langsung (Direct Instruction). Penelitian ini merupakan penelitian eksperimen dengan desain penelitianyaitu Pretes-Post-test two treatment design. Populasi dalam penelitian ini adalah siswa kelas VIII salah satu MTsN di Pekanbaru. Sampel untuk penelitian ini diambil dua kelas sebagai kelas eksperimen dengan menggunakan teknik purposive sampling. Instrumen yang digunakan berupa soal tes kemampuan berpikir kritis. Temuan penelitian ini adalah: (1) Kemampuan berpikir kritis matematis siswa yang memperoleh pembelajaran dengan pendekatan Problem Posing lebih baik daripada siswa yang memperoleh Pembelajaran langsung (Direct Instruction) dan (2) Peningkatan kemampuan berpikir kritis matematis siswa yang memperoleh pembelajaran dengan pendekatan Problem Posing lebih baik daripada siswa yang memperoleh Pembelajaran langsung (Direct Instruction).

Kata kunci: Kemampuan Berpikir Kritis Matematis, Pendekatan
\end{abstract}

\section{ABSTRACT}

This study aims to examine enhancement of critical thinking ability of the students who got learning with problem posing approach and the students who got direct instruction. This study employed experimental research with Pretest-Post-test two treatment design. The population in this study were class VIII the students of one MTsN in Pekanbaru. For sample for this study, two classes were taken as experimental class by using purposive sampling technique. The instruments which were used were in the forms of critical thinking ability tests. The findings of this study were: (1) Critical thinking ability of the students who get learning with Problem Posing approach was better than the students who got Direct Instruction and (2) The enhancement of mathematical critical thinking ability of the students who got learning with Problem Posing approach was better than the students who got Direct Instruction.

Keywords: Mathematical Critical Thinking Ability, Problem Posing Approach, Direct Instruction. 


\section{Problem Posing, \\ Pembelajaran Langsung \\ (Direct Instruction).}

\section{How to Cite: Trisnawati, R., Wahyudin, \& Kusnadi. (2017). Studi Komparatif Tentang Peningkatan Kemampuan Berpikir Kritis Matematis Siswa MTs yang Memperoleh Pembelajaran dengan Pendekatan Problem Posing dan Pembelajaran Langsung. Mathline: Jurnal Matematika dan Pendidikan Matematika, Vol.2, No.1, 57-70.}

\section{PENDAHULUAN}

Berpikir kritis merupakan tujuan pendidikan yang harus dikembangkan dalam proses pembelajaran di sekolah. Sebagai usaha untuk menyiapkan generasi penerus bangsa yang berkualitas dan tangguh dalam menghadapi tantangan dimasa yang akan datang. Salah satu cara yang dapat dilakukan untuk mewujudkan tujuan tersebut yaitu dengan mempelajari matematika disetiap jenjang pendidikan di Indonesia. Muijz \& Reynolds (2008) mengungkapkan bahwa,"matematika merupakan kendaraan utama untuk mengembangkan kemampuan berpikir logis dan keterampilan kognitif yang lebih tinggi pada anak-anak".

Sumarmo (2013) menjelaskan bahwa,"matematika memiliki dua visi, yaitu: Visi pertama mengarahkan pembelajaran matematika untuk pemahaman konsep dan ide matematika yang kemudian diperlukan untuk menyelesaikan masalah matematika dan ilmu pengetahuan lainnya. Visi yang kedua dalam arti yang lebih luas dan mengarah ke masa depan, matematika memberi peluang berkembangnya kemampuan menalar yang logis, sistematik, kritis dan cermat, kreatif, menumbuhkan rasa percaya diri, dan rasa keindahan terhadap keteraturan sifat matematika, serta mengembangkan sikap objektif dan terbuka yang sangat diperlukan dalam menghadapi masa depan yang selalu berubah. Jadi pembelajaran matematika merupakan sarana untuk mengembangkan kemampuan berpikir kritis yang dibutuhkan dalam mengahapi tantangan dalam kehidupan di masa yang akan datang”.

Hasil penelitian yang dilakukan Syahbana (2012) pada siswa SMP menunjukkan bahwa kemampuan berpikir kritis dapat ditingkatkan, namun dari hasil postes pada kelas eksperimen diperoleh rata-rata kemampuan berpikir kritis matematis yaitu 68, jika di dalam skala 0-100 nilai ini termasuk ke dalam kategori cukup. Penelitian lain yang berkaitan dengan berpikir kritis adalah penelitian tindakan kelas yang dilakukan oleh Sulistyani (2012) pada siswa SMP diperoleh rata-rata hasil pada siklus I sebesar 54,36\% 
termasuk ke dalam kategori sedang. Rata-rata kemampuan berpikir kritis matematis siswa pada siklus II sebesar 84,13\% termasuk ke dalam kategori tinggi. Penelitian ini menunjukkan bahwa kemampuan berpikir kritis matematis siswa dapat ditingkatkan.

Salah satu pendekatan yang diduga dapat meningkatkan kemampuan berpikir kritis siswa adalah pendekatan Problem Posing. Sutawidjaja \& Dahlan, (2011) menyatakan bahwa "pendekatan Problem Posing adalah alat untuk mengembangkan, meningkatkan, atau memperkuat keterampilan berpikir kritis".

Nisbet mengungkapkan bahwa,"tidak ada cara belajar (tunggal) yang paling benar, dan cara mengajar yang paling baik, setiap orang berbeda dalam kemampuan intelektual, sikap, dan kepribadian sehingga mereka mengadopsi pendekatan-pendekatan yang karakteristiknya berbeda untuk belajar",(Suherman, dkk., 2003). Hal ini berarti bahwa masing-masing individu akan memilih cara dan gayanya sendiri untuk belajar dan untuk mengajar, namun setidak-tidaknya ada karakteristik tertentu dalam pendekatan pembelajaran tertentu yang khas dibandingkan pendekatan lain. Hal ini senada dengan yang disampaikan oleh Sutawidjaja \& Dahlan (2011) bahwa,"tidak ada cara atau strategi/model pembelajaran terbaik, yang ada adalah ketepatan dalam memilih strategi/model pembelajaran”.Menurut Ruseffendi (1991), “ada empat faktor yang menjadi pertimbangan bagi guru dalam memilih metode pembelajaran, yaitu: (1) tujuan instruksional; (2) materi yang diajarkan; (3) kondisi/lingkungan; (4) siswa”.

Problem Posing adalah suatu reaksi siswa terhadap situasi yang telah disediakan oleh guru. Reaksi tersebut dapat berupa respon dalam bentuk peryataan, pertanyaan nonmatematika atau pertanyaan matematika, terlepas dari apakah pertanyaan matematika tersebut pada akhirnya dapat dipecahkan atau tidak (Sutawidjaja \& Dahlan, 2011).

Auerbach, "menetapkan lima langkah dalam mengimplementasikan pendekatan

Problem Posing, yaitu: (1) Gambarkan Situasi (Describe the Content); (2) Rumuskan Masalah (Define the Problem); (3) Pikirkan Dan Rasakan Adanya Masalah (Personalize the Problem); (4) Diskusi Masalah (Discuss the Problem); (5) Diskusikan Beberapa Alternatif Pemecahan (Discuss Alternatives to the Problem)", (Sutawidjaja \& Dahlan, 2011).

Dari lima langkah-langkah pembelajaran dalam pendekatan Problem Posing, tergambar bahwa siswa dituntun untuk meningkatkan kemampuan berpikir kritis, hal ini sejalan dengan indikator-indikator kemampuan berpikir kritis yang diutarakan oleh Sumarmo (2013) yaitu: 
(1) mencari pernyataan, pertanyaan dan alasan secara jelas; (2) memahami informasi dengan baik dengan cara memilih sumber yang terpercaya; (3) memperhatikan situasi dan kondisi secara keseluruhan; (4) bersikap tegap dengan ide utama; (5) menjaga keaslian dan mendasar; (6) mencari alternatif, bersikap dan berpikir terbuka, sistematis dan teratur; (7) mengambil posisi disertai bukti yang cukup; (8) mencari penjelasan sebanyak mungkin.

Untuk melihat sejauhmana keutamaan dan efektifitas pendekatan Problem Posing dalam rangka meningkatkan kemampuan berpikir kritis matematis siswa, maka perlu dibandingkan dengan pendekatan lain. Pendekatan Problem Posing digunakan di kelas ekperimen yang pertama sedangkan pembelajaran langsung (Direct Instruction) digunakan di kelas eksperimen yang kedua. pembelajaran langsung (Direct Instruction) juga dikenal dengan sebutan pengajaran aktif (Active Teaching) atau pengajaran seluruh kelas (Wholeclass Teaching), yaitu suatu pembelajaran di mana guru terlibat secara aktif untuk mengusung isi pelajaran kepada siswa-siwanya dengan mengajarkannya secara langsung kepada seluruh kelas. Namun demikian bukan berarti pembelajaran langsung (Direct Instruction) adalah metode pembelajaran yang buruk.

Berdasarkanpenelitian yang dilakukan oleh Good \& Brophy (Muijs \& Reynolds, 2008) menghasilkan suatu kesimpulan bahwa "pembelajaran langsung (Direct Instruction) merupakan metode terbaik untuk mengajarkan tentang aturan, prosedur, dan keterampilan dasar khususnya untuk murid-murid belia. Tetapi bukan berarti bahwa pembelajaran langsung (Direct Instruction) adalah metode terbaik untuk digunakan di semua keadaan".

Leung (2013) mengklasifikasikan pertanyaan yang diajukan siswa menjadi lima jenis, yaitu: (1) Not a Problem (bukan merupakan suatu masalah); (2) Non Math (bukan merupakan masalah matematika);(3) imposible (tidak mungkin);(4) insufficien (masalah matematika yang mengandung informasi yang tidak lengakap untuk menjawab masalah tesebut); (5) sufficient (permasalahan matematika yang memberikan informasi yang lengkap sehingga dapat diperoleh penyelesaiannya)".

Dalam hal ini siswa diharapkan mampu mengajukan pertanyaan matematika yang termasuk jenis ke-lima yaitu pertanyaan yang sufficient (permasalahan matematika yang memberikan informasi yang lengkap sehingga dapat diperoleh penyelesaiannya).

Silver \&Cai (Haji, 2011) membuat diagram dari berbagai respon yang muncul dalam pendekatan pembelajaran problem posing yaitu sebagai berikut: 


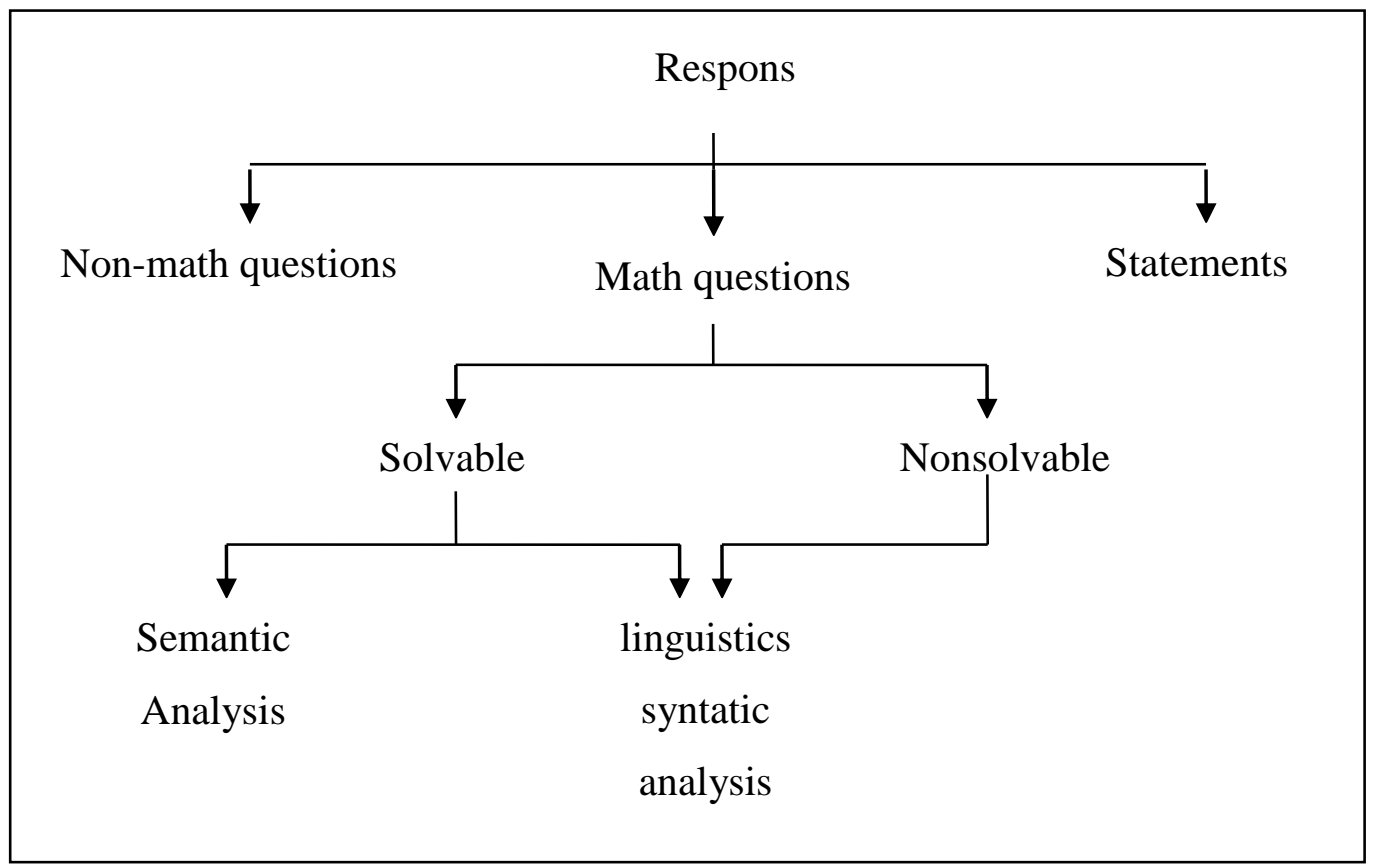

Gambar 1. Bagan Jenis Respon Siswa yang Muncul ketika Pembelajaran Problem Posing

Ada dua teori belajar yang mendasari pendekatan Problem Posing, yaitu: (1) teori belajar Jerome S. Bruner; dan (2) teori belajar Robert M. Gagne mengenai stimulusrespon, rangkaian verbal dan pemecahan masalah.

Tabel 1. Indikator Kemampuan Berpikir Kritis yang Diteliti

\begin{tabular}{|c|c|c|}
\hline NO & $\begin{array}{l}\text { Keterampilan } \\
\text { Berpikir Kritis }\end{array}$ & Keterangan \\
\hline 1 & Focus (fokus) & \multirow{2}{*}{$\begin{array}{l}\text { Fokus terhadap situasi yang menggambarkan masalah utama. } \\
\text { Mengidentifikasi, menjastifikasi, merumuskan argumentasi } \\
\text { dan membuat keputusan dalam menyelesaikan masalah. }\end{array}$} \\
\hline 2 & Reasons (alasan) & \\
\hline 3 & $\begin{array}{l}\text { Inference } \\
\text { (inferensi) }\end{array}$ & Melakukan inferensi terhadap kesimpulan yang diputuskan. \\
\hline 4 & Situation (situasi) & \multirow{2}{*}{$\begin{array}{c}\text { Relevansi terhadap situasi yang sebenarnya. } \\
\text { Kejelasan terhadap istilah-istilah yang dipakai dalam } \\
\text { argumen. }\end{array}$} \\
\hline 5 & Clarify (klarifikasi) & \\
\hline 6 & $\begin{array}{c}\text { Overview } \\
\text { (keseluruhan) }\end{array}$ & Memeriksa kembali apa yang telah ditemukan. \\
\hline \multicolumn{3}{|c|}{ Modifikasi dari Ennis (1996) } \\
\hline
\end{tabular}


yaitu suatu pembelajaran yang melibatkan guru secara aktif untuk mengusung isi pelajaran kepada siswa-siwanya dengan mengajarkannya secara langsung kepada seluruh kelas. Joyce, Weil \& Calhoun (2009) menyatakan, "ada lima langkah pembelajaran langsung yaitu: (1) Orientasi; (2) Presentasi; (3) Praktik yang terstruktur; (4) Praktik di bawah bimbingan; (5) Praktik mandiri”.

Teori belajar yang mendukung pembelajaran langsung (direct instruction) adalah teori belajar behavioral dan teori belajar sosial. Ada banyak tokoh-tokoh yang berpengaruh dalam teori behavioral antara lain: Ivan Pavlov, John Watson, Edward Thorndike, dan B.F Skinner. Joyce, Weil \& Calhoun (2009) menyatakan bahwa, "ahli psikologi behavioral lebih membahas mengenai modeling, penguatan (reinforcement), respon balik (feedback), dan perkiraan suksesif (successive approximation)".

Teori belajar behavioris yang sangat berpengaruh dalam pembelajaran langsung adalah teori belajar dari Skinner tentang operant conditioning. Menurut Skinner (Hergenhahn \& Olson, 2012), "belajar akan berlangsung sangat efektif apabila: (1) informasi yang akan dipelajari disajikan secara bertahap; (2) pembelajaran segera diberi umpan balik (fedback) mengenai akurasi pembelajaran mereka (yakni, setelah belajar mereka segera diberi tahu apakah mereka sudah memahami informasi dengan benar atau tidak); dan (3) siswa mampu belajar dengan caranya sendiri”.

Permasalahan dalam penelitian ini yaitu: kemampuan berpikir kritis yang belum berkembang dengan baik dalam pembelajaran matematika dan penerapan pendekatan problem posing dan pembelajaran langsung yang diduga dapat menjawab permasalahn tentang kemampuan tersebut.

Berdasarkan identifikasi permasalahan di atas, maka diketahui masalah utama dalam penelitian ini adalah "Apakah terdapat perbedaan kemampuan dan perbedaan peningkatkan kemampuan berpikir kritis matematis siswa yang memperoleh pembelajaran dengan pendekatan problem posing dan siswa yang memperoleh pembelajaran langsung (Direct Instruction)?". Masalah ini dapat dijabarkan ke dalam beberapa pertanyaan penelitian sebagai berikut:

1. Apakah kemampuan berpikir kritis matematis siswa yang memperoleh pembelajaran dengan pendekatan Problem Posing lebih baik daripada siswa yang memperoleh Pembelajaran langsung (Direct Instruction)? 
2. Apakahpeningkatan kemampuan berpikir kritis matematis siswa yang memperoleh pembelajaran dengan pendekatan Problem Posing lebih baik daripada siswa yang memperoleh Pembelajaran langsung (Direct Instruction)?

Secara umum penelitian ini bertujuan untuk memperoleh gambaran tentang peningkatan kemampuan berpikir kritis matematis siswa melalui pendekatan problem posing. Secara lebih khusus penelitian ini bertujuan untukmengetahui apakah:

1. Kemampuan berpikir kritis matematis siswa yang memperoleh pembelajaran dengan pendekatan problem posinglebih baik dibandingkan siswa yang memperoleh Pembelajaran langsung (Direct Instruction).

2. Peningkatan kemampuan berpikir kritis matematis siswa yang memperoleh pembelajaran dengan pendekatan problem posinglebih baikdibandingkan siswa yang memperoleh Pembelajaran langsung (Direct Instruction).

\section{METODE PENELITIAN}

Penelitian ini merupakan penelitian eksperimen dengan disain "Pretes-Post-test two treatment design". Pada penelitian ini ada dua kelas sebagai subjek penelitian. Kedua kelas ini diberikan pretes dan postes.

Pretes diberikan sebelum proses pembelajaran dalam penelitian ini dimulai, sedangkan postes diberikan setelah keseluruhan proses pembelajaran selesai. Pretes diberikan bertujuan untuk melihat kesetaraan kemampuan awal dari kedua kelompok kelas. Sedangkan postes diberikan bertujuan untuk mengetahui sejauh mana pengaruh pembelajaran yang diberikan terhadap peningkatan kemampuan siswa. Pada penelitian ini subjek tidak dikelompokkan secara acak. Pola rancangan digambarkan sebagai berikut:

Kelas Eksperimen $_{1} \quad: \mathrm{O}_{1} \quad \mathrm{X}_{1} \quad \mathrm{O}_{2}$

Kelas Eksperimen $_{2} \quad: \mathrm{O}_{1} \quad \mathrm{X}_{2} \quad \mathrm{O}_{2}$

Keterangan:

$\mathrm{O}_{1}$ : Pretes kemampuan berpikir kritis matematis siswa.

$\mathrm{O}_{2}$ : Postes kemampuan berpikir kritis matematis siswa

$\mathrm{X}_{1}$ : Pembelajaran matematika dengan pendekatan Problem Posing.

$\mathrm{X}_{2}$ : Pembelajaran matematika dengan pembelajaran langsung (direct instruction).

(Cohen, Manion \& Morrison, 2007)

Jenis data yang telah dikumpulkan adalah data kuantitatif, berupa data hasil tes kemampuan berpikir kritis matematis siswa. Data-data yang telah dikumpulkan selanjutnya 
dianalisis dengan bantuan program sofeware SPSS versi 20.0 for windowsdan Microsoft Excel 2007.

Data hasil tes kemampuan berpikir kritis matematis siswa di analisis berdasarkan pengolahan data kuantitatif yang bertujuan untuk mengetahui besarnya peningkatan kemampuan berpikir kritis matematis siswa. Data hasil pretes dan postes yang telah diperoleh dianalisis melalui tahapan-tahapan sebagai berikut:

(a) Menghitung statistik deskriptif skor pretes, skor postes dan gain yang meliputi skor minimum, skor maksimum, rata-rata dan simpangan baku.

(b) Menghitung besarnya peningkatan kemampuan berpikir kritis matematis siswa yang diperoleh dari skor pretes dan postes dengan menggunakan rumus gain ternormalisasi yang dikembangkan oleh Hake (Meltzer, 2002), yaitu :

Gain ternormalisasi $($ gain $)=\frac{\text { skor postes }- \text { skor pretes }}{\text { skor maksimal-skor pretest }}$

(c) Hasil perhitungan gain ternormalisasi kemudian diinterpretasikan dengan menggunakan klasifikasi yang dinyatakan oleh Hake (1999) sebagai berikut:

Tabel 2. Klasifikasi Gain Ternormalisasi

\begin{tabular}{cc}
\hline Besarnya Gain $($ g) & Interpretasi \\
\hline $0,7<$ g $\leq 1,00$ & Tinggi \\
$0,3<$ g $\leq 0,7$ & Sedang \\
g $\leq 0,3$ & Rendah \\
\hline
\end{tabular}

(d) Melakukan uji normalitas pada data skor pretes dan postes dan gain ternormalisasi untuk tiap kelompok dengan rumusan hipotesis sebagai berikut:

$H_{0}$ : data berdistribusi normal

$H_{1}$ : data berdistribusi tidak normal

Uji statistik yang digunakan adalah One-Sample Kolmogorov-Smirnov dengan kriteria pengujian adalahtolak $\mathrm{H}_{0}$ apabila Sig.(p-value $)<$ taraf signifikansi $(\alpha=0,05)$, untuk kondisi lainnya $\mathrm{H}_{0}$ diterima.

(e) Melakukan uji homogenitas varians. Pengujuan varians antara kelompok eksperimen dan kelompok kontrol dilakukan untuk mengetahui apakah varian kedua kelompok sama atau berbeda. Selain itu, pengujian ini dilakukan untuk pengolahan data selanjutnya apakah menggunakan uji t atau uji t'. Adapun hipotesis yang akan diuji adalah: 
$H_{0}$ : varians kedua data homogen

$H_{1}$ : varians kedua data tidak homogen

Uji statistik dalam melakukan uji homogenitas menggunakan uji Levene dengan kriteria pengujian adalah tolak $\mathrm{H}_{0}$ apabila Sig. $(P$-Value $)<$ taraf signifikansi $(\alpha=0,05)$, untuk kondisi lainnya $\mathrm{H}_{0}$ diterima.

(f) Jika kedua rata-rata skor berdistribusi normal dan homogen maka uji statistik yang digunakan adalah uji-t.

(g) Jika data berdistribusi normal tetapi tidak homogen, maka uji statistik yang digunakan adalah uji-t'.

(h) Apabila data berdistribusi tidak normal, maka uji statistik yang digunakan adalah dengan pengujian non-parametrik, yaitu dengan uji mann-whitney.Uji Mannwhitney atau U-tes merupakn alternatif lain dari t-tes jika asumsi distribusi normalitas sampel dan homogenitas tidak terpenuhi (Susetyo, 2010).

Penentuan sampel dilakukan dengan carapurposive sampling dikenal juga dengan teknik pengambilan sampel pertimbangan yaitu teknik pengambilan sampel yang digunakan peneliti jika peneliti mempunyai pertimbangan-pertimbangan tertentu di dalam pengambilan sampelnya atau pengambilan sampel untuk tujuan tertentu (Riduwan \& Akdon, 2010). Sampel pada penelitian ini adalah kelas eksperimen pertama yaitu siswa kelas VIII.7 (sebanyak 35 siswa) dan kelas eksperimen kedua yaitu siswa di kelas VIII.8 (sebanyak 34 siswa) dengan mengambil kelas yang sudah ada agar tidak mengganggu proses pembelajaran.

Alur penelitian di bawah ini menggambarkan langkah awal sebelum dilaksanakannya penelitian hingga diperoleh kesimpulan untuk menjawab hipotesis yang diajukan. Adapun alur tersebut dapat dilihat pada bagan berikut: 


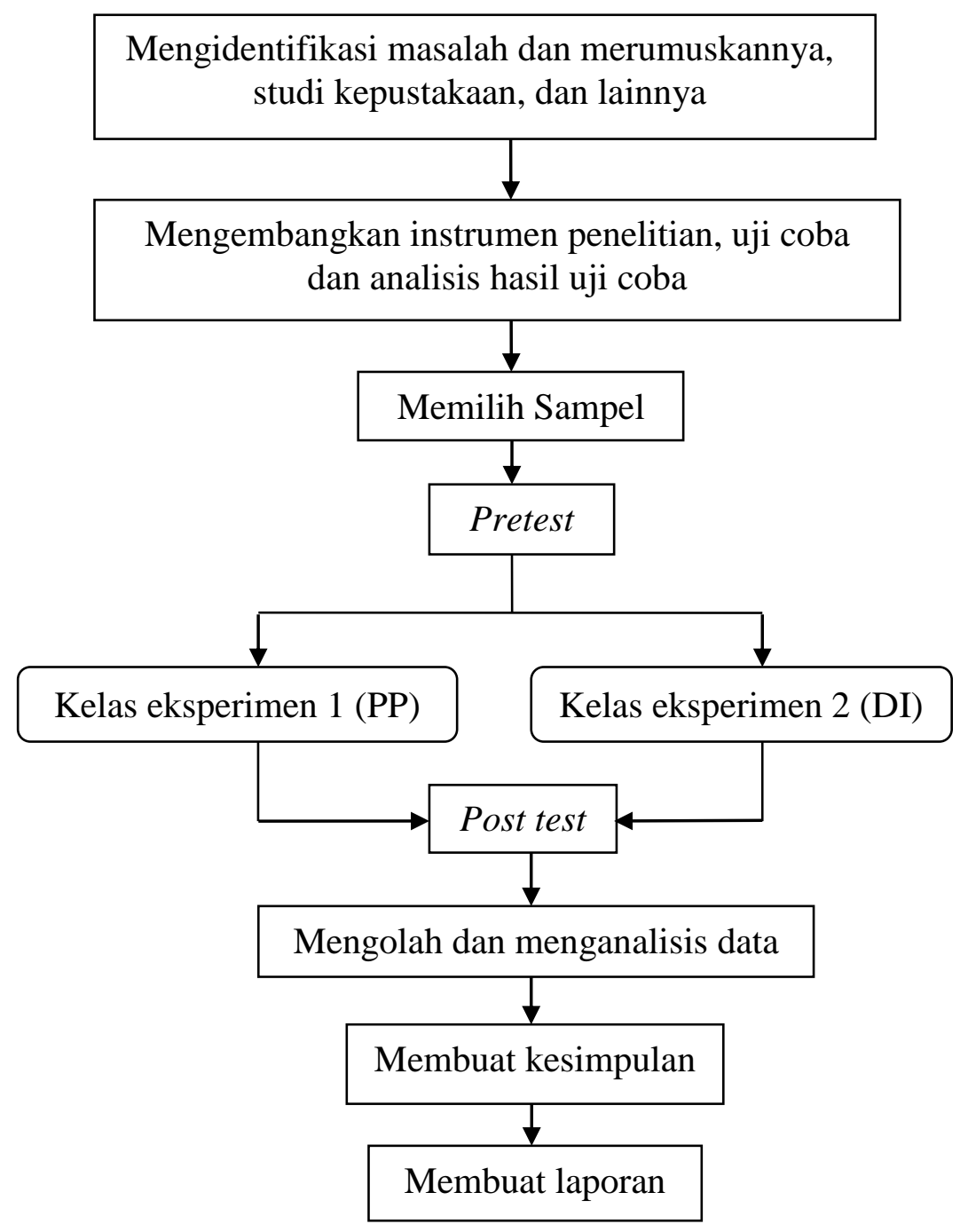

Gambar 2. Diagram Alur Penelitian

\section{HASIL PENELITIAN DAN PEMBAHASAN}

Tes kemampuan berpikir kritis dalam penelitian ini terdiri dari enam soal uraian. Setiap soal tersebut mencerminkan satu indikator dari kemampuan berpikir kritis, yaitu: (1) fokus terhadap situasi yang menggambarkan masalah utama; (2) mengidentifikasikan, menjastifikasikan, merumuskan argumentasi dan membuat keputusan dalam menyelesaikan masalah; (3) melakukan inferensi terhadap kesimpulan yang diputuskan; (4) relevasi terhadap situasi yang sebenarnya; (5) kejelasan terhadap istilah-istilah yang dipakai dalam argumen; dan (6) memeriksa kembali apa yang telah ditemukan. Berikut ini merupakan salah satu jawaban siswa dari setiap kelas eksperimen untuk soal kemampuan 
berpikir kritis yang mencerminkan indikator kemampuan berpikir kritis yang kelima yaitu kejelasan terhadap istilah-istilah yang dipakai dalam argumen.

Imam memiliki kerangka balok yang terbuat dari kawat dengan ukuran panjang $25 \mathrm{~cm}$, lebar $20 \mathrm{~cm}$ dan tinggi $15 \mathrm{~cm}$. Jika kerangka kawat tersebut dibuka dan dibentuk sebuah bangun yang berbentuk kubus dengan ukuran terbesar. Tentukan perbedaan volume dari kedua bangun tersebut!

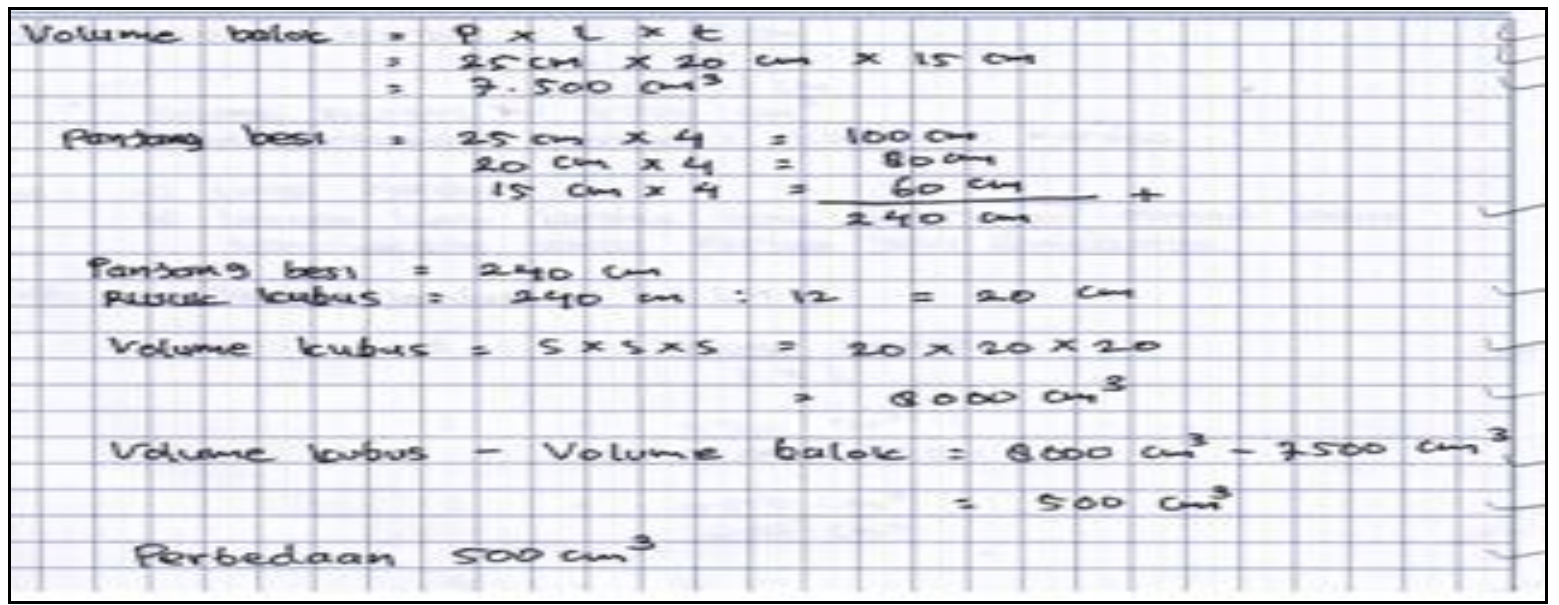

Gambar 3. Hasil Jawaban Postes Kemampuan Berpikir Kritis Matematis Salah Satu Siswa di Kelas PP

Imam memiliki kerangka balok yang terbuat dari kawat dengan ukuran panjang $25 \mathrm{~cm}$, lebar $20 \mathrm{~cm}$ dan tinggi $15 \mathrm{~cm}$. Jika kerangka kawat tersebut dibuka dan dibentuk sebuah bangun yang berbentuk kubus dengan ukuran terbesar. Tentukan perbedaan volume dari kedua bangun tersebut!

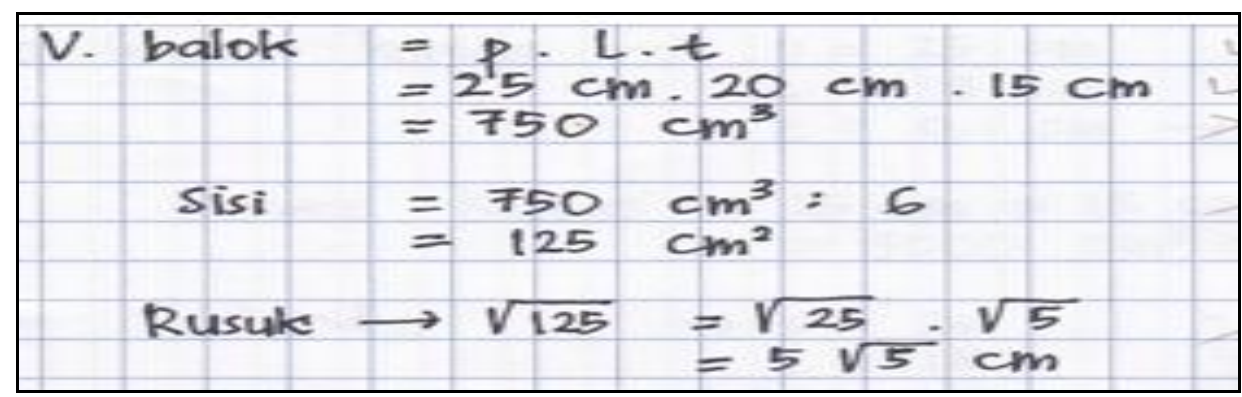

Gambar 4. Hasil Jawaban Postes Kemampuan Berpikir Kritis Matematis Salah Satu Siswa di Kelas DI

Gambar di atas memperlihatkan bahwa langkah awal yang dikerjakan siswa dikedua kelas eksperimen sama, namun pada langkah selanjutnya siswa di kelas DI tidak 
dapat menyelesaiakan persoalan tersebut dengan benar karena siswa kurang memahami soal tersebut dan melakukan kesalahan dalam perhitungan.

Rata-rata skor Gainkemampuan berpikir kritis matematis siswa dari kelas eksperimen satu (PP) dan siswa dari kelas eksperimen dua (DI) menunjukkan bahwa peningkatan kemampuan berpikir kritis matematis siswa pada kelaseksperimen satu (PP) termasuk ke dalam kategori sedang, namun peningkatan kemampuan berpikir kritis matematis siswa pada kelas eksperimen dua (DI) termasuk ke dalam kategori rendah.

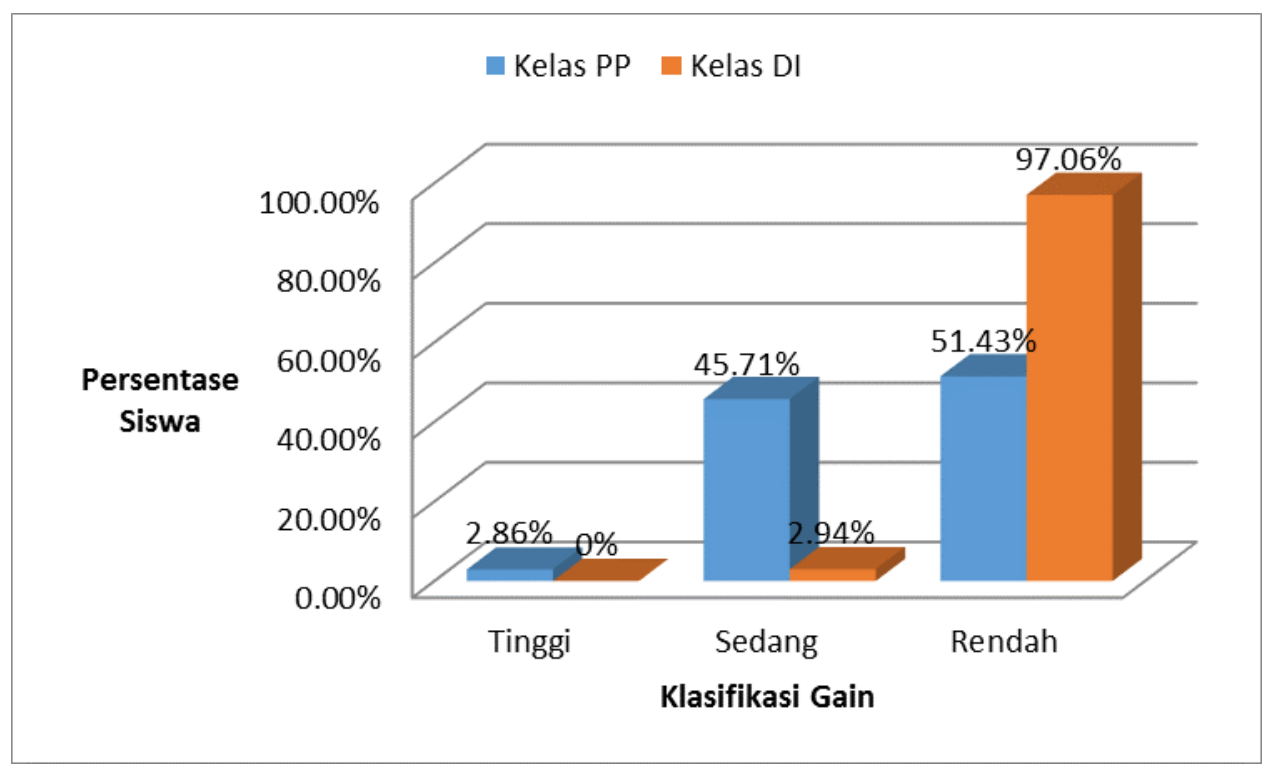

Gambar 5. Diagram Klasifikasi Gain Kemampuan Berpikir Kritis Matematis Siswa.

Dilihatdari nilai deviasi standar Gain kemampuan berpikir kritis matematis siswa pada kelas eksperimen satu (PP) lebih baik daripada nilai standar deviasi Gain kemampuan berpikir kritis matematis siswa pada kelas eksperimen dua (DI). Hal ini mengindikasikan bahwa peningkatan kemampuan berpikir kritis matematis siswa pada kelas eksperimen satu yaitu kelas yang memperoleh pembelajaran dengan pendekatan Problem Posing lebih baik daripada peningkatan kemampuan berpikir kritis matematis siswa pada kelas eksperimen dua yaitu siswa yang memperoleh pembelajaran langsung (Direct Instruction). Hal ini sesuai dengan apa yang dikemukakan oleh Dewey (Fisher, 2009) bahwa mengajukan pertanyaan (Problem Posing) merupakan salah satu proses aktif yang secara esensial dilakukan dalam proses berpikir kritis. 


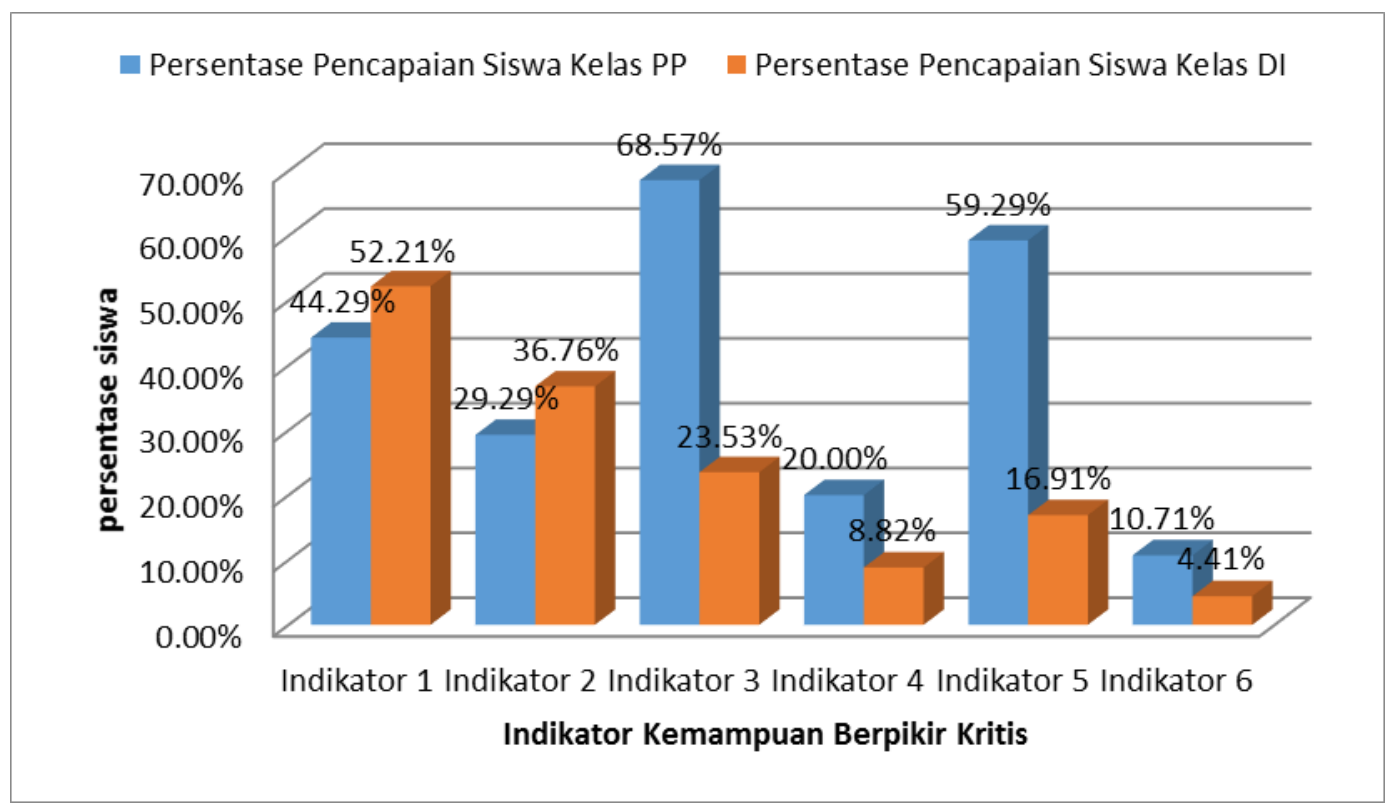

Gambar 6. Persentase Pencapaian Kemampuan Berpikir Kritis Matematis Siswa Untuk

Setiap Indikator di kedua Kelas Eksperimen

Melalui pendekatan problem posing siswa dilatih untuk menemukan suatu konsep berdasarkan situasi yang telah disediakan guru. Siswa diberikan alat peraga untuk memudahkan mereka dalam menemukan jawaban dari pertanyaan yang telah mereka ajukan. Dengan adanya alat peraga siswa terlihat lebih antusias selama pembelajaran berlangsung. Hal ini sesuai dengan teori belajar Bruner yang mengatakan bahwa dalam proses belajar sebaiknya siswa diberikan kesempatan untuk memanipulasi benda-benda (alat peraga), karena melalui alat peraga yang diteliti tersebut siswa akan melihat langsung bagaimana keteraturan dan pola terstruktur yang terdapat pada benda yang sedang diperhatikannya.

\section{KESIMPULAN}

Berdasarkan analisis hasil penelitian dan pembahasan yang telah dikemukakan di atas, maka dalam bab ini akan dikemukakan beberapa kesimpulan sebagai berikut:

1. Kemampuan berpikir kritis matematis siswa yang memperoleh pembelajaran dengan pendekatanProblem Posing lebih baik daripada siswa yang memperoleh Pembelajaran langsung (Direct Instruction).

2. Peningkatan kemampuan berpikir kritis matematis siswa yang memperoleh pembelajaran dengan pendekatan Problem Posing lebih baik daripada siswa yang memperoleh Pembelajaran langsung (Direct Instruction). 


\section{DAFTAR PUSTAKA}

Cohen, L., Manion, L. \& Morrison, K. (2007). Research Methods in Education (6th edition). USA \& Canada: Routledge.

Ennis, R. H. (1996). Critical Thinking. United State of America: Prentice-Hall Inc.

Fisher, A. (2009). Berpikir Kritis: sebuah pengantar (Benyamin Hadinata, Penerjemah). Jakarta: Erlangga.

Haji, S. (2011). Pendekatan Problem Posing dalam Pembelajaran Matematika Di Sekolah Dasar. Jurnal Kependidikan Triadik, 14, (1), 55-63.

Hake, R.R. (1999). Analyzing Changel Gain Scores. [Online] Tersedia: http://www.physics.indiana.edu/ sdi/Analyzingchange-Gain.pdf [21 Oktober 2013].

Hergenhahn, B. R. \& Olson, M. H. (2012). Teori Belajar (Triwibowo.B.S, Penerjemah). Jakarta: Kencana.

Joyce, Weil \& Calhoun. (2009). Models of Teaching: Model-Model Pengajaran (Achmad Fawaid \& Ateilla Mirza, Penerjemah). Yogyakarta: Pustaka Pelajar.

Leung, S.S. (2013). Teacher Implementing Mathematical Problem Posing in the Classroom: challenges and strategies. Educational Studies in Mathematics an International Journal, 83, (1), 103-116.

Meltzer, D. E. (2002). Addendum to : The Relationship between Mathematics Preparation and Conceptual Learning Gain in Physics : A Possible "Hidden Variable" in Diagnostics Pretest Score". [Online] Tersedia: http//www.physics.iastes.edu/per/docs/addendum on_normalized_gain. [21 Oktober 2013].

Muijz, D. \& Reynolds, D. (2008). Efective Teaching: teori dan aplikasi (Helly Prajitno Soejipto \& Sri Mulyantini Soejipto, Penerjemah). Yogyakarta: Pustaka Pelajar.

Riduwan \& Akdon. (2010). Rumus dan Data dalam Analisis Statistika. Bandung: Alfabeta.

Ruseffendi, H. E. T. (1991). Pengantar Kepada Membantu Guru Mengembangkan Kompetensinya dalam Pengajaran Matematika untuk Meningkatkan CBSA. Bandung: Tarsito.

Suherman, E., dkk. (2003). Strategi Pembelajaran Matematika Kontemporer. Bandung: Universitas Pendidikan Indonesia.

Sulistyani, N. (2012, November). Implementasi Pembelajaran Berbasis Masalah Dipadukan dengan Model Pembelajaran Kooperatif Tipe TAI (Team Assisted Individualization) untuk Meningkatkan Kemampuan Berpikir Kritis Matematis Pada Siswa SMPN 2 Sentolo Kelas IXA. Makalah pada Seminar Nasional Matematika dan Pendidikan Matematika FMIPA UNY, Yogyakarta.

Sumarmo, U. (2013). Kumpulan Makalah: Berpikir dan Disposisi Matematik Serta Pembelajarannya. Bandung: Universitas Pendidikan Indonesia.

Susetyo, B. (2010). Statistika untuk Analisis Data Penelitian. Bandung: Refika Aditama.

Sutawidjadja, A. \& Dahlan, J. A. (2011). Pembelajaran Matematika. Jakarta: Universitas Terbuka.

Syahbana, A. (2012). Peningkatan Kemampuan Berpikir Kritis Matematis Siswa SMP Melalui Pendekatan Contextual Teaching and Learning. Edumatica,02, (01), 45-57. 